\title{
An Analysis of Working Conditions of Filipinos in Malta
}

\author{
Manwel Debono, PhD \\ Mario Thomas Vassallo, PhD \\ University of Malta, Malta
}

\begin{abstract}
Malta is experiencing a strong economic growth which is attracting increasing numbers of foreign workers. This study investigates the working conditions experienced by Filipinos in Malta, the largest group of migrants from outside the European Union. Survey data collected from a sample of 317 Filipino workers was compared to the results of the Sixth European Working Conditions Survey. While most respondents experience positive work outcomes, a significant minority grapples with negative conditions and perceptions. Overall, the Filipino respondents in Malta appear to face more difficult working conditions than other migrants in Europe. Nearly half of the respondents report that their health or safety is at risk because of their work and over a fourth suffered from discrimination during the year leading to the research. A substantial minority of Filipinos work below their skill levels and more than 40 hours per week. About a third of the respondents are not satisfied with their working conditions, claim not to be treated fairly at work and do not find sufficient help and support from their managers and colleagues. This study indicates the need to take into consideration the realities of both the home and host countries when analyzing the working situation of migrants. It highlights the employment vulnerability of migrant Filipino workers in Malta, and points to an apparent structural deficiency in the Maltese society to protect them.
\end{abstract}

Keywords: Filipinos; migrants; working conditions; vulnerability; EWCS

\section{Introduction}

This study intends to explore the working experiences, perceptions and attitudes of Filipino workers in the small European country of Malta. The interest in Filipino workers stems from their growing numbers and their potential labour market vulnerability amid the rising negative sentiment of the Maltese population towards foreigners (European Commission, 2018b). 
Situated in the middle of the Mediterranean Sea, Malta is among the fastest growing economies in the EU (European Commission, 2018c). Such growth is resulting in an increasingly problematic shortage of labour supply, creating difficulties for employers in various sectors. It has been reported that in 2017, more than $30 \%$ of companies in Malta registered labour shortages constraining their business, with the most striking difficulties in services subsectors such as healthcare, finance and ICT (European Commission, 2018a). The influx of foreign workers over the last years has been substantial, growing four-fold between 2010 and 2017 (Jobsplus, 2018b). Currently, about a fifth of all workers in Malta are foreigners, when compared to about $1 \%$ in 2000 (Central Bank of Malta, CBM, 2016), and their number is set to continue rising (Times of Malta, 2019). Foreign workers in Malta are most likely to be employed in specific services subsectors, especially remote gaming, tourism, and professional services and administrative support, which together include nearly half of all foreign employees (CBM, 2016). Foreigners are often employed at either the upper or the lower ends of the labour market. Whereas EU migrants tend to occupy high skilled jobs for which there are insufficient trained Maltese people, third country nationals often do low skilled jobs that are unattractive to Maltese people (CBM, 2016).

Filipinos are the largest group of third country nationals in Malta. They tend to work in elementary occupations (43.3\%) often as cleaners, or in services and sales (39.3\%), especially as care-workers (Jobsplus, 2018a). The Filipino migrant community in Malta is in large part made of women and young workers (Jobsplus, 2018a). The number of registered Filipino workers in Malta grew six-fold between 2010 and 2018 (from 459 to 2,882), and is set to keep on growing. This trend is especially fuelled by the country's prosperity and ageing population, a situation which is resulting in an ever expanding health sector which attracts growing numbers of foreign workers, especially Filipinos. With its explicit nurse export policy, the Philippines is a key supplier of nurses and health workers globally (Singh, 2012). In line with other Western countries, Malta is moving from a passive to a more active international recruitment of workers in the health sector (Malta Independent, 2011), thus playing a growing role in what is often referred to as the 'global care chain' (Basa, Harcourt, \& Zarro, 2011).

Working conditions in Malta are governed by the Employment and Industrial Act (Government of Malta, 2002) and related laws. Such legal framework incorporates EU directives and is in line with EU employment policies. Over half of all employees are also covered by more detailed collective agreements (Debono, 2018). The country's average net income ranks $15^{\text {th }}$ highest among the 28 member states (Eurostat, 2019). Malta is also one of the EU countries with a minimum wage. Overall levels of satisfaction with the working conditions compare well with those of other EU countries 
(Eurofound, 2017). While workers in Malta tend to work longer hours than the EU average, their working hours fit in relatively well with family and social commitments (Eurofound, 2017). On the other hand, workers in Malta are more likely to believe that their health or safety is at risk because of their work (Eurofound, 2017), though work-related injury and fatality rates have been decreasing over the past years (Occupational Health and Safety Authority, Malta, 2019. The participation of workers in lifelong education and training has grown considerably over the last decade but is still lower than the EU average (Eurostat, 2019). While working conditions in Malta are generally good by European standards, very little scientific evidence exists about the working conditions of migrant workers in this country.

This study aims to add a piece in the complex puzzle that makes up the experiences of the estimated 800,000 Filipinos living in the European Union (EU) (CNN Philippines, 2018). Research indicates that third country nationals in Europe face greater hardships than EU nationals or EU internal migrants (OECD, 2018). However, there exists little information about the working conditions of Filipinos in Europe in general and far less in Malta. This country's successful policy to attract foreign workers appears not to have been complemented by an appropriate effort to treat these individuals with the respect they deserve. Thus, it is hypothesized that Filipino workers in Malta experience higher levels of negative work-related outcomes in comparison to Maltese citizens, EU nationals, and migrants in general within the EU28 member states.

\section{The working situation of migrants within the EU and beyond}

Migration is an important global phenomenon with complex economic, political, social and personal ramifications. Research shows that migrants tend to experience more vulnerable work than natives (e.g. Ambrosini \& Barone, 2007). However, their situation might vary on the basis of many factors, such as gender, country of origin, destination country, compatibility of cultures, length of stay in destination country, legal status and laws of the land, demographics, qualifications, employment sector, occupation and recruitment process experienced. Vulnerability appears to increase due to 'intersectionality', when different forms of social stratification interconnect and amplify the disadvantages of particular groups of migrants. For example, migrant women working without a formal contract as live-in carers might be more vulnerable than migrant women working on an indefinite contract as nurses in a hospital.

Instances of blatant migrant slavery in the EU are relatively rare. However, research reports problematic gaps between laws and practice in the EU (Islam, Cojocaru, Rahman, Hajar, \& Arnakim, 2016). Even in EU countries where integration policies and welfare state institutions are highly 
developed, studies reveal that significant proportions of migrants might suffer from "poor working conditions, unemployment and homelessness" (Spehar, Hinnfors, \& Bucken-Knapp, 2017, p. 114). Migrants might be subjected to lower working conditions while remaining within the legal boundaries, for instance by working in sectors which pay less. Thus, they end up contributing to social dumping and fuelling the dual economy. Besides, governments even within the EU might sometimes implement policies and enact laws with the purpose of oppressing migrants (e.g. Sales, 2007). This proposition is not outlandish, especially during the current period of xenophobic attitudes taking over many countries across the world.

The following subsections review relevant literature on a number of important dimensions in the working situation of migrants. Findings from the Sixth European Working Conditions Survey (6th EWCS) are discussed in relation to other research carried out in specific countries within and outside the EU. The situation of migrant workers in Malta and Filipino migrant workers in general is highlighted whenever possible.

\section{Working contracts}

The 6th EWCS indicates that migrants tend to have different types of working contracts when compared to nationals (Eurofound, 2017). They are more likely to: be employees rather than self-employed, work in the private sector, work on contracts of limited duration, or work without a contract. Ambrosini and Barone (2007) remark that self-employment among migrants in the EU might not be on the increase just because migrants are becoming more entrepreneurial. It might also be the result of organisations adopting strategies that force migrants to sell their services as self-employed. The overrepresentation of migrants in temporary contracts might be due to a variety of factors such as the exclusive availability of work permits of limited duration, seasonal recruitment in particular sectors, the widespread availability of temporary contracts in certain public sector jobs, and the existence of temporary work agencies that specialise in recruiting migrant workers (Ambrosini \& Barone, 2007).

The 6th EWCS also indicates that migrants are more likely to work less than 35 hours per week (Eurofound, 2017). This finding is not straightforward since other studies carried out in specific countries both within and outside the EU suggest that foreigners tend to work longer hours than natives (e.g. Chen, 2017; Ronda et al., 2013).

According to the 6th EWCS, migrants are more likely to be underemployed than nationals (Eurofound, 2017). Despite their academic qualifications, migrants within EU member states often end up in low-paid and insecure jobs (Ambrosini \& Barone, 2007). The OECD (2018) suggests that $39 \%$ of third country nationals in the EU, amounting to 5.7 million people, 
live in relative poverty. This is a much higher percentage than that of EU nationals $(17 \%)$ or EU internal migrants $(24 \%)$. It has been argued that Mediterranean countries are more likely to employ lower-skilled migrants when compared to the northern European countries (Ambrosini \& Barone, 2007). A study carried out among 158 migrant workers in Spain claims that many of them are overqualified for their work, a situation which may lead to negative health and safety consequences (Ahonen et al., 2009). Similarly, a study carried out among 282 Latin Americans living in Germany indicates that $63 \%$ of the respondents work below their skill level, and this is related to poor psychosocial well-being (Espinoza-Castro, Rueda, Lopez, \& Radon, 2018). Another European study concludes that educational mismatch (both over- and under-education) among foreign-born workers in Sweden increases their risk of ill health (Dunlavy, Garcy, \& Rostila, 2016).

A study carried out by Semyonov and Gorodzeisky (2004) among 2,346 households in the Philippines suggests that Filipino overseas workers tend to be employed in low-status, manual and service jobs. At the same time, the study reveals that many Filipino workers were unemployed prior to migration (Semyonov \& Gorodzeisky, 2004). Migration appears to offer the opportunity for many Filipinos to land their first job. It is interesting to note that even when migrants work in professional jobs, their work might be devalued in the host country, as highlighted by England and Henry (2013) and Calenda (2014) when discussing the situation of migrant nurses working in the UK. Migrant workers might also be stuck in the first job they land in the host country. Maltese research shows that migrants are unlikely to change their job or improve their occupation while in Malta (Borg, 2019).

Several studies highlight that migrants are often required to be flexible in their working arrangements, including having to carry out tasks that go beyond their job description (e.g. Ambrosini \& Barone, 2007; Ayalon, 2009; Ollus, 2016). A qualitative study carried out in the cleaning industry in Finland contends "that the demand and need for (employee) flexibility may turn into forced flexibility that exploits the powerless and vulnerable migrant workers who have few other options than to agree to work on poor terms" (Ollus, 2016, p. 25). Such a demand for flexibility might explain how despite the lower working hours, migrant workers in the EU feel that their working hours fit less well with their family or social commitments when compared to nationals (Eurofound, 2017).

\section{Fair treatment}

According to the 6th EWCS, migrants are more likely to feel that they are not being treated fairly at work (Eurofound, 2017). They also receive less help and support from their managers and their colleagues at work when compared to nationals (Eurofound, 2017). This finding is corroborated by 
other studies in the EU, for example among Filipino-born nurses in the UK (Calenda, 2014), and among migrants of different nationalities in Spain (Ahonen et al., 2009).

Overall, migrants working in the EU earn lower wages than nationals, a situation that may be affected by their relatively low average age and the type of sectors they end up working in (Ambrosini \& Barone, 2007). Also, in view of their greater likelihood of underemployment, it is not surprising that migrant workers in the EU more often feel that they are not getting paid appropriately (Eurofound, 2017). Despite the above, research suggests that while Filipino migrant women tend to earn less than men, both genders earn much more than what they would have earned in their home country (Semyonov \& Gorodzeisky, 2004).

Migrant workers in Europe are more likely to experience some form of discrimination when compared to nationals (Eurofound, 2017). A systematic review of literature about working conditions and occupational health among immigrants in Europe and Canada confirms that perceived discrimination or bullying is consistently higher among migrant workers than natives (Sterud et al., 2018). Similarly, a systematic review of studies among migrant and minority nurses indicates that discrimination is their main cause of ill health (Schilgen, Nienhaus, Handtke, Schulz, \& Mösko, 2017). A case study about migrant nurses within the Maltese healthcare system also reveals that they are discriminated by managers, colleagues and patients (Buttigieg, Agius, Pace, \& Cassar, 2018). They are reprimanded more often for minor misdemeanours and suffer from unequal opportunities with regards to wages and promotions. According to the OECD (2018), nearly a fifth of third-country nationals in the EU experience discrimination, a figure that increases considerably in some member states.

\section{Health and safety}

Migrants working in European countries are more likely than nationals to believe that their health or safety is at risk because of their work (Eurofound, 2017). This finding is in line with extensive international research showing that the health of migrant workers tends to be at a greater risk than that of nationals. "Work injuries were consistently found to be more prevalent among immigrants in studies from different countries and in studies with different designs" (Sterud et al., 2018, p. 1). However, "the evidence that immigrant workers are more likely to be exposed to physical or chemical hazards and poor psychosocial working conditions is very limited" (Sterud et al., 2018, p. 1). Several reasons have been proposed for the higher accident rates among migrant workers, such as their propensity to work in high risk sectors, their excessive risk taking (to demonstrate their commitment due to their fear of losing their job), poor communication skills and on-the job training, and 
longer and more intensive working hours when compared to nationals (Koukoulaki, 2010). While no statistics are available on migrants' injuries in Malta, the country's Occupational Health and Safety Authority (OHSA) recognizes that the construction section, which is particularly prone to injuries, relies heavily on migrant workers (OHSA, 2019).

Migrant workers may also be more exposed to violence at work. Espinoza-Castro et al. (2018) report that 14\% of their sample of Latin American migrants living in Germany experienced workplace violence during the year before the study. Some research carried out outside the EU appears to show more alarming trends. For example, in a study among 187 Filipino home care workers in Israel, "more than half of the participants reported exposure to abuse (e.g. sexual, physical, or emotional) or exploitation (e.g. asking to do more than job requirements)" (Green \& Ayalon, 2017, p. 1001). Migrants were especially vulnerable in their first year in the host country and when they took care of older adults with cognitive impairments. Counter intuitively, male migrant workers were also more at risk of abuse than females (Ayalon, 2017). A low level of unionization is among the factors that may increase the risk of violence at the workplace (Pillinger, 2016). A significant link between exposure to work-related abuse and burnout has been reported among migrants (Ayalon, 2009).

Research indicates that migrants may be willing to accept poor working conditions as inherent parts of work (Ahonen et al., 2009) and are likely to endure great work hardships (del Castillo \& Marzadro, 2014). For example, when compared to nationals, migrants in the EU tend to take less sick leave (Eurofound, 2017). Migrants living in Belgium, Italy, Malta, Portugal and Spain, especially third country nationals, have less access to preventive health services than native people (Rosano et al., 2017). Predictably, the situation of such migrants worsens in countries with less organised health services. Similarly, according to studies carried out in other countries such as the USA and Canada, migrants make low use of mental health services (Kirmayer et al., 2007). Considering the above, it is not surprising that research highlights 'unrecognised mental health needs' among the difficulties encountered by migrant live-in care workers (Vahabi \& Wong, 2017).

\section{Career development, training and job satisfaction}

"Migrant workers are not only segregated into low-paid jobs, but they also have little likelihood of progressing out of them" (Ambrosini \& Barone, 2007 , p. 35). Underemployment may result in deskilling (e.g. Vahabi \& Wong, 2017), potentially leading to future career difficulties.

The fact that migrants in the EU are less likely to undergo training (Eurofound, 2017) does not help their job prospects. Lower levels of training 
have also been documented among migrant workers in hotels in UK, indicating that "that employers are unwilling to invest in the development of international staff who have high levels of general education and training that is not sector specific" (Baum et al., 2007, p. 229). On the other hand, it has been pointed out that sometimes, training and information might not be possible due to language difficulties (e.g. Koukoulaki, 2010). Research carried out in Malta indicates that the relatively short stay of foreign workers in the country may also create disincentives for employers to train them (Borg, 2019).

Overall job security is largely related to the prevailing economic situation in the country. However, when compared to nationals, migrants in the EU experience less job security and are more likely to feel that they might lose their job in the ensuing six months (Eurofound, 2017). A study among Filipino- and Indian-born nurses in the UK reveals concerns about precariousness and potential job loss when employers have to manage funding reductions in the public health sector (Calenda, 2014). Due to such situation, a substantial proportion of respondents believe not to have professional and career prospects in the UK (Calenda, 2014).

As expected, migrants in the EU tend to feel less satisfied with the working conditions in their main paid job when compared to nationals (Eurofound, 2017). Research proposes that job satisfaction can increase through greater role discretion (Iecovich, 2011; Supangco \& Mayrhofer, 2014). However, according to the 6th EWCS, when compared to nationals, migrants working in EU countries have less control over their work and can exert less influence on important work decisions. Lack of power to manage one's work has also been documented in other studies on migrant workers (e.g. Chowdhury \& Gutman, 2012).

Live-in carers are among the most vulnerable group of migrant workers. However, a study carried out in Canada reveals that despite their challenges, these workers held mostly positive attitudes toward their work and life (Chowdhury \& Gutman, 2012). Interestingly, the participants in this study focus on the intrinsic rewarding aspects of the job, such as the opportunity to help others and the learning experienced, rather than on the negative external aspects related to their employment.

\section{Methodology}

Aims

The study aims to investigate some important dimensions of working conditions of Filipino migrants in Malta. It is hypothesised that such migrants experience relatively high levels of negative work-related outcomes. A quantitative methodology is used in order to capture the attitudes and perspectives of a wide spectrum of these workers. A cross-sectional design 
based on a survey enables the analysis of patterns of association between the variables of interest in this study.

\section{Sample}

Data derives from a sample of 317 Filipinos working in Malta, 24\% of whom are men and $76 \%$ are women. The large majority of the respondents are between 25 and 39 years old $(58.4 \%)$, have a post-secondary or university education (82.6\%), and have resided in Malta from 1 to 5 years $(59.7 \%)$. The sample constitutes about $11 \%$ of all the Filipino workers in Malta and roughly reflects their demographic characteristics.

\section{Data capturing tool}

Data was collected through a brief survey consisting of mainly closeended questions about demographics, general employment information, working conditions and other perceptions. Most of the survey questions were based on the 6th EWCS questionnaire (Eurofound, 2019) to allow for comparisons with the European survey results.

\section{Procedure}

A meeting was organized with a number of Filipino community leaders in which the research aims were explained and the assistance of the leaders was sought for the distribution of the survey. A hard copy of the survey was developed, piloted and slightly modified before it was finalized and sent to the community leaders for their endorsement. Data was gathered in two stages. 91 properly filled questionnaires were gathered by the researchers during a Christmas party organized jointly by the Filipino associations in Malta on the 16th December 2018. Subsequently, in order to boost the replies, an online version of the questionnaire was developed through Kwiksurveys.com and was distributed with the help of Filipino contacts. Another 226 properly filled questionnaire were derived through this method in January 2019.

Data were inputted into the Statistical Package for the Social Sciences (SPSS) and were cleaned by identifying and fixing inaccuracies. Then they were amalgamated with the dataset of the 6th EWCS (Eurofound, 2017). This procedure was possible as the two datasets were based on data derived from similar questions and were collected over a rather brief period of time (three years) from one another. Subsequently, data were analysed through descriptive and inferential statistics. Percentages were first derived to indicate the main trends of four groups of workers, namely Filipino migrants, Maltese citizens, Other EU nationals, and Migrants within the EU28 member states. Subsequently, chi-squares were used to test any significant differences between the four demographic groups. 


\section{Ethical issues}

Ethical considerations were prioritised during the data collection process due to the potential vulnerability of the respondents arising from their foreign nationality. Both versions of the questionnaire were accompanied by an introductory note explaining the purpose of the research, ensuring the anonymity of responses and providing the contact details of the authors in case of any difficulties.

\section{Results}

The results deriving from the current survey are provided in comparison to the 6th EWCS data for Maltese nationals, Other EU nationals, and Migrants in the EU28 member states. The results are divided according to six tables showing: general aspects of the job; working time and job control; qualifications, skills and training; health and safety; job satisfaction, fairness and support; and employment security.

As can be seen in Table 1 below, nearly all Filipino respondents are employees (96.8\%) employed on a full-time basis $(95.9 \%)$, a figure which is significantly higher than those of the three comparison groups, $\chi 2(3, \mathrm{~N}=$ $32,585)=141.23, \mathrm{p}<.001$. At $85.6 \%$, a larger percentage of respondents work in the private sector when compared to the comparison groups, $\chi 2(3, \mathrm{~N}=$ $30,962)=125.56, \mathrm{p}<.001$. Besides, close to half of the respondents $(43.8 \%)$ are employed on a definite contract, a figure which is also considerably higher than the comparison groups, $\chi 2(6, \mathrm{~N}=27,878)=878.60, \mathrm{p}<.001$. On the other hand, only $3.2 \%$ of the Filipino respondents are in high skilled jobs, a figure which is significantly lower than those of the comparison groups, $\chi 2$ (3, $\mathrm{N}=32,676)=239.96, \mathrm{p}<.001$. 
Table 1. General aspects of the job

\begin{tabular}{|l|l|l|l|l|l|l|}
\hline & $\begin{array}{l}\text { Filip. } \\
\text { Malta }\end{array}$ & $\begin{array}{l}\text { Malt. } \\
\text { Nat.* }\end{array}$ & $\begin{array}{l}\text { Other } \\
\text { EU } \\
\text { Nat.* }\end{array}$ & $\begin{array}{l}\text { EU28 } \\
\text { Mig.* }\end{array}$ & $N$ & $\boldsymbol{P}$ \\
\hline $\begin{array}{l}\text { Employment } \\
\text { Employee } \\
\text { Self-employed }\end{array}$ & $\mathbf{9 6 . 8}$ & 88.2 & 85.2 & 87.7 & 32,778 & $51.88^{* *}$ \\
\hline $\begin{array}{l}\text { Full-/Part-time } \\
\text { Full-time }\end{array}$ & $\mathbf{3 . 2}$ & 11.8 & 14.8 & 12.3 & & \\
Part-time & $\mathbf{9 5 . 9}$ & 87.7 & 81.2 & 75.0 & 32,585 & $141.23^{* *}$ \\
\hline $\begin{array}{l}\text { Contract type } \\
\text { Indefinite }\end{array}$ & $\mathbf{4 . 1}$ & 12.3 & 18.8 & 25.0 & & \\
Definite & $\mathbf{5 3 . 5}$ & 67.5 & 82.6 & 73.9 & 27,878 & $878.60^{* *}$ \\
No contract & $\mathbf{4 3 . 8}$ & 8.2 & 12.4 & 18.8 & & \\
\hline $\begin{array}{l}\text { Sector } \\
\text { Public }\end{array}$ & $\mathbf{2 . 7}$ & 24.3 & 5.0 & 7.3 & & \\
Private & $\mathbf{1 4 . 4}$ & 35.1 & 26.0 & 19.1 & 30,962 & $125.56^{* *}$ \\
\hline $\begin{array}{l}\text { Job category*** } \\
\text { High skilled }\end{array}$ & $\mathbf{8 5 . 6}$ & 64.9 & 74.0 & 80.9 & & \\
Low skilled & $\mathbf{1 3 . 2}$ & 56.3 & 53.0 & 46.9 & 32,676 & $239.96^{* *}$ \\
\hline
\end{tabular}

* Source: Eurofound, 2017; ** P $<0.001$

*** High skilled category consists of: legislators, senior officials and managers; professionals; technicians and associate professionals; skilled agricultural and fishery workers; craft and related trades workers. Low skilled category consists of: clerks; service workers and shop and market sales workers; plant and machine operators and assemblers; elementary occupations.

Most Filipino respondents $(60 \%)$ usually work less than 41 hours per week in their main paid job (see Table 2 below). However, the $40 \%$ of Filipinos who work 41+ hours per week represent a significantly higher ratio of persons than the comparison groups, $\chi 2(3, \mathrm{~N}=32,062)=49.21, \mathrm{p}<.001$. Filipino workers are also more likely to feel that their working hours do not fit in well with their family or social commitments outside work $\chi 2(3, \mathrm{~N}=$ $32,729)=44.34, \mathrm{p}<.001$. At the same time, two thirds $(67.9 \%)$ of the Filipino respondents are often able to influence decisions that are important for their work, a much larger figure than that of the comparison groups, $\chi^{2}(6, \mathrm{~N}=$ $32,127)=227.23, \mathrm{p}<.001$. 
Table 2. Working time and job control

\begin{tabular}{|l|l|l|l|l|l|l|}
\hline & $\begin{array}{l}\text { Filip. } \\
\text { Malta }\end{array}$ & $\begin{array}{l}\text { Malt. } \\
\text { Nat.* }\end{array}$ & $\begin{array}{l}\text { Other } \\
\text { EU } \\
\text { Nat.* }\end{array}$ & $\begin{array}{l}\text { EU28 } \\
\text { Mig.* }\end{array}$ & N & $\boldsymbol{P}$ \\
\hline $\begin{array}{l}\text { Normal weekly } \\
\text { working hours (main } \\
\text { job) }\end{array}$ & & & & & & \\
$<41$ hours & $\mathbf{6 0}$ & 72.6 & 75.4 & 77.4 & 32,062 & $49.21^{* *}$ \\
$41+$ hours & $\mathbf{4 0}$ & 27.4 & 24.6 & 22.6 & & \\
\hline Fit of working hours & & & & & & \\
with family/ social & & & & & & \\
commitments & & & & & \\
Well & $\mathbf{7 5 . 9}$ & 82.1 & 82.2 & 77.7 & 32,729 & $44.34^{* *}$ \\
Not well & $\mathbf{2 4 . 1}$ & 17.9 & 17.8 & 22.3 & & \\
\hline $\begin{array}{l}\text { Able to influence } \\
\text { important work }\end{array}$ & & & & & & \\
decisions & & & & & & \\
Always/Mostly & $\mathbf{6 7 . 9}$ & 55.8 & 48.4 & 45.2 & 32,127 & \\
Sometimes/Rarely & $\mathbf{2 7 . 4}$ & 30.9 & 37.9 & 32.6 & & \\
Never & $\mathbf{4 . 7}$ & 13.3 & 13.7 & 22.2 & & \\
\hline
\end{tabular}

*Source: Eurofound, 2017; ** P $<0.001$

Filipino workers are by far the most qualified out of the four examined groups of workers (see Table 3 below), $\chi^{2}(3, \mathrm{~N}=32,755)=224.82, \mathrm{p}<.001$. They are also significantly more likely to believe that they have the skills to cope with more demanding duties, $\chi^{2}(6, \mathrm{~N}=32,560)=62.10, \mathrm{p}<.001$. Filipino workers appear to be less likely than the comparison groups to have received on-the-job training over the year leading to the survey, $\chi^{2}(3, \mathrm{~N}=$ $32,759)=42.28, \mathrm{p}<.001$. At the same time, they are more likely to have engaged in training paid for by themselves, $\chi^{2}(3, \mathrm{~N}=32,789)=85.20, \mathrm{p}<$ .001 . Finally, together with EU28 migrants, they are less likely to have received training paid for or provided by their employer when compared to nationals, $\chi 2(3, \mathrm{~N}=28,230)=35.09, \mathrm{p}<.001$.

As can be seen from Table 4, nearly half of the Filipino respondents (47.7\%) believe that their health or safety is at risk because of their work, a figure which is significantly higher than those of the comparison groups, $\chi^{2}$ $(3, N=32,279)=96.1, p<.001$. During the year leading to the survey, Filipino workers were also more likely to have suffered from workplace discrimination or bullying/harassment (27.2\% and $10.7 \%$ respectively) when compared to the other three groups. However, the four groups of workers report similarly low levels of physical violence or sexual harassment. A significantly lower ratio of Filipino workers was never absent from work due to sick leave or health related leave during the year leading to the survey, though fewer Filipinos took $4+$ days of sick leave, $\chi^{2}(6, \mathrm{~N}=29,891)=392.80, \mathrm{p}<.001$. 
Table 3. Qualifications, skills and training

\begin{tabular}{|c|c|c|c|c|c|c|}
\hline & $\begin{array}{l}\text { Filip. } \\
\text { Malta }\end{array}$ & $\begin{array}{l}\text { Malt. } \\
\text { Nat.* }\end{array}$ & $\begin{array}{l}\text { Other } \\
\text { EU Nat.* }\end{array}$ & $\begin{array}{l}\text { EU28 } \\
\text { Mig.* }\end{array}$ & $N$ & $P$ \\
\hline $\begin{array}{l}\text { Highest qualification } \\
\text { completed } \\
\text { Secondary or less } \\
\text { Post-sec./tertiary }\end{array}$ & $\begin{array}{l}17.4 \\
82.6\end{array}$ & $\begin{array}{l}64.6 \\
35.4 \\
\end{array}$ & $\begin{array}{l}57.4 \\
42.6\end{array}$ & $\begin{array}{l}57.3 \\
42.7\end{array}$ & 32,755 & $224.82 * *$ \\
\hline $\begin{array}{l}\text { Description of skills in } \\
\text { work } \\
\text { I need further training } \\
\text { to cope well with my } \\
\text { duties } \\
\text { My present skills } \\
\text { correspond well with } \\
\text { my duties } \\
\text { I have the skills to cope } \\
\text { with more demanding } \\
\text { duties }\end{array}$ & $\begin{array}{l}7.3 \\
52.7 \\
40.0\end{array}$ & $\begin{array}{l}17.4 \\
60.8 \\
21.8\end{array}$ & $\begin{array}{l}13.7 \\
57.9 \\
28.5\end{array}$ & $\begin{array}{l}13.2 \\
55.2 \\
31.6\end{array}$ & 32,560 & $62.10 * *$ \\
\hline $\begin{array}{l}\text { Training paid for/ } \\
\text { provided by employer } \\
\text { over past year } \\
\text { Yes } \\
\text { No }\end{array}$ & $\begin{array}{l}34.7 \\
65.3\end{array}$ & $\begin{array}{l}40.2 \\
59.8\end{array}$ & $\begin{array}{l}40.1 \\
59.9\end{array}$ & $\begin{array}{l}34.5 \\
65.6\end{array}$ & 28,230 & $35.09 * *$ \\
\hline $\begin{array}{l}\text { Training paid for by } \\
\text { respondent over past } \\
\text { year } \\
\text { Yes } \\
\text { No } \\
\end{array}$ & $\begin{array}{l}24.3 \\
75.7\end{array}$ & $\begin{array}{l}11.7 \\
88.3\end{array}$ & $\begin{array}{l}9.4 \\
90.6\end{array}$ & $\begin{array}{l}9.2 \\
90.8\end{array}$ & 32,789 & $85.20 * *$ \\
\hline $\begin{array}{l}\text { On-the-job training } \\
\text { over past year } \\
\text { Yes } \\
\text { No }\end{array}$ & $\begin{array}{l}21.5 \\
78.5\end{array}$ & $\begin{array}{l}38.4 \\
61.6\end{array}$ & $\begin{array}{l}34.8 \\
65.2 \\
\end{array}$ & $\begin{array}{l}30.9 \\
69.1\end{array}$ & 32,759 & $48.28 * *$ \\
\hline
\end{tabular}

*Source: Eurofound, 2017; ** P < 0.001 
Table 4. Health and safety

\begin{tabular}{|c|c|c|c|c|c|c|}
\hline & $\begin{array}{l}\text { Filip. } \\
\text { Malta }\end{array}$ & $\begin{array}{l}\text { Malt. } \\
\text { Nat.* }\end{array}$ & $\begin{array}{l}\text { Other } \\
\text { EU } \\
\text { Nat.* }\end{array}$ & $\begin{array}{l}\text { EU28 } \\
\text { Mig.* }\end{array}$ & $N$ & $P$ \\
\hline $\begin{array}{l}\text { Health or safety at risk } \\
\text { because of work } \\
\text { Yes } \\
\text { No } \\
\end{array}$ & $\begin{array}{l}47.7 \\
52.3 \\
\end{array}$ & $\begin{array}{l}26.1 \\
73.9 \\
\end{array}$ & $\begin{array}{l}25.7 \\
74.3 \\
\end{array}$ & $\begin{array}{l}30.2 \\
69.8 \\
\end{array}$ & 32,279 & $96.11 * *$ \\
\hline $\begin{array}{l}\text { Subjected to } \\
\text { discrimination during } \\
\text { previous year } \\
\text { Yes } \\
\text { No }\end{array}$ & $\begin{array}{l}27.2 \\
72.8\end{array}$ & $\begin{array}{l}4.5 \\
95.5\end{array}$ & $\begin{array}{l}6.4 \\
93.6\end{array}$ & $\begin{array}{l}15.9 \\
84.1\end{array}$ & 32,574 & $538.54 * *$ \\
\hline $\begin{array}{l}\text { Subjected to physical } \\
\text { violence during previous } \\
\text { year } \\
\text { Yes } \\
\text { No } \\
\end{array}$ & $\begin{array}{l}3.5 \\
96.5\end{array}$ & $\begin{array}{l}1.3 \\
98.7 \\
\end{array}$ & $\begin{array}{l}1.9 \\
98.1 \\
\end{array}$ & $\begin{array}{l}2.1 \\
97.9 \\
\end{array}$ & 32,705 & 5.42 \\
\hline $\begin{array}{l}\text { Subjected to sexual } \\
\text { harassment during } \\
\text { previous year } \\
\text { Yes } \\
\text { No }\end{array}$ & $\begin{array}{l}0.5 \\
99.5\end{array}$ & $\begin{array}{l}0.2 \\
99.8\end{array}$ & $\begin{array}{l}0.8 \\
99.2\end{array}$ & $\begin{array}{l}0.8 \\
99.2\end{array}$ & 32,688 & 4.33 \\
\hline $\begin{array}{l}\text { Subjected to bullying/ } \\
\text { harassment during } \\
\text { previous year } \\
\text { Yes } \\
\text { No }\end{array}$ & $\begin{array}{l}10.7 \\
89.3\end{array}$ & $\begin{array}{l}6.1 \\
93.9\end{array}$ & $\begin{array}{l}4.4 \\
95.6\end{array}$ & $\begin{array}{l}7.1 \\
92.9\end{array}$ & 32,678 & $67.14 * *$ \\
\hline $\begin{array}{l}\text { Days absent due to sick/ } \\
\text { health-related leave } \\
\text { during previous year } \\
\text { None } \\
1-3 \\
4+\end{array}$ & $\begin{array}{l}30.0 \\
41.3 \\
28.7\end{array}$ & $\begin{array}{l}35.3 \\
23.9 \\
40.9\end{array}$ & $\begin{array}{l}56.4 \\
12.9 \\
30.7\end{array}$ & $\begin{array}{l}57.5 \\
15.3 \\
27.2\end{array}$ & 29,891 & $392.80 * *$ \\
\hline
\end{tabular}

*Source: Eurofound, 2017; ** P < 0.001

While most Filipino respondents are satisfied with their working conditions in their main job $(65.1 \%)$, their level of satisfaction is significantly lower than that of the comparison groups (see Table 5), $\chi^{2}(3, \mathrm{~N}=32,742=$ $155.98, \mathrm{p}<.001$. Most Filipino respondents also feel that they are treated fairly at their workplace $(67.3 \%)$ and that their managers and colleagues help and support them (69.3\% and $70.7 \%$ respectively). However, overall they are much more pessimistic than the comparison groups with regards to their perception of fair treatment, $\chi 2(6, \mathrm{~N}=27,930)=169.39, \mathrm{p}<.001$. Besides, they are also more pessimistic with regards to the perceived support from colleagues $\chi^{2}(6, \mathrm{~N}=29,172)=96.58, \mathrm{p}<.001$. While Filipino respondents experience less help and support from their managers when compared to 
Maltese nationals, the experience appears to be worse among EU28 migrants, $\chi 2(6, N=27,362)=188.18, p<.001$. On the other hand, Filipino workers are less likely to feel that they are being paid inappropriately considering the efforts and achievements in their job, $\chi 2(6, \mathrm{~N}=32,226)=92.01, \mathrm{p}<.001$.

Table 5. Job satisfaction, fairness and support

\begin{tabular}{|l|l|l|l|l|l|l|}
\hline & $\begin{array}{l}\text { Filip. } \\
\text { Malta }\end{array}$ & $\begin{array}{l}\text { Malt. } \\
\text { Nat. }\end{array}$ & $\begin{array}{l}\text { Other } \\
\text { EU } \\
\text { Nat.* }\end{array}$ & $\begin{array}{l}\text { EU28 } \\
\text { Mig.* }\end{array}$ & N & P \\
\hline $\begin{array}{l}\text { Overall satisfaction } \\
\text { with working } \\
\text { conditions }\end{array}$ & & & & & & \\
Satisfied & $\mathbf{6 5 . 1}$ & 85.7 & 85.9 & 80.7 & 32,742 & $155.98^{* *}$ \\
Not satisfied & $\mathbf{3 4 . 9}$ & 14.3 & 14.1 & 19.3 & & \\
\hline Treated fairly & & & & & & \\
Always/Mostly & $\mathbf{6 7 . 3}$ & 81.7 & 83.7 & 79.3 & 27,930 & $169.39^{* *}$ \\
Sometimes/Rarely & $\mathbf{2 1 . 7}$ & 15.8 & 14.5 & 17.2 & & \\
Never & $\mathbf{1 1 . 0}$ & 2.5 & 1.9 & 3.5 & & \\
\hline Paid appropriately & $\mathbf{5 1 . 0}$ & 46.9 & 50.2 & 49.4 & 32,226 & $92.01^{* *}$ \\
Agree & $\mathbf{3 0 . 4}$ & 16.5 & 18.8 & 14.8 & & \\
Unsure & $\mathbf{1 8 . 5}$ & 36.6 & 31.0 & 35.8 & & \\
Disagree & & & & & & \\
\hline Manager helps \& & & & & 61.7 & 27,362 & $188.18^{* *}$ \\
supports & $\mathbf{6 9 . 3}$ & 82.5 & 64.2 & 61.7 & \\
Agree & $\mathbf{2 2 . 3}$ & 15.7 & 29.9 & 28.4 & & \\
Unsure & $\mathbf{8 . 4}$ & 1.8 & 5.9 & 9.9 & & \\
Disagree & & & & & & \\
\hline Colleagues help \& & & & & & & \\
support & $\mathbf{7 0 . 7}$ & 87.1 & 75.8 & 73.8 & 29,172 & $96.58^{* *}$ \\
Agree & $\mathbf{1 9 . 7}$ & 11.1 & 20.0 & 20.0 & & \\
Unsure & $\mathbf{9 . 6}$ & 1.7 & 4.2 & 6.2 & & \\
Disagree & & & & & & \\
\hline
\end{tabular}

*Source: Eurofound, 2017; ** $\mathrm{P}<0.001$

Table 6 shows that while most Filipino respondents do not think that they will lose their job in the following 6 months $(54.2 \%)$, the ratio is significantly lower than those of EU28 migrants and Other EU nationals, $\chi 2$ $(6, \mathrm{~N}=29,334)=253.69, \mathrm{p}<.001$. A large minority of Filipinos are unsure about this item. Besides, most Filipino respondents are unsure whether it would be easy to find a job of similar salary if they lose or quit their job $(52.4 \%)$. The figure is significantly higher than that of the comparison groups, $\chi 2(6, N=29,958)=354.67, p<.001$. 
Table 6. Employment security

\begin{tabular}{|l|l|l|l|l|l|l|}
\hline & $\begin{array}{l}\text { Filip. } \\
\text { Malta }\end{array}$ & $\begin{array}{l}\text { Malt. } \\
\text { Nat.* }\end{array}$ & $\begin{array}{l}\text { Other EU } \\
\text { Nat.* }\end{array}$ & $\begin{array}{l}\text { EU28 } \\
\text { Mig.* }\end{array}$ & $\boldsymbol{N}$ & $\boldsymbol{P}$ \\
\hline $\begin{array}{l}\text { Might lose job in } \\
\text { the next 6 months }\end{array}$ & & & & & & \\
Agree & $\mathbf{9 . 1}$ & 9.4 & 16.7 & 20.0 & 29,334 & $253.69 * *$ \\
Unsure & $\mathbf{3 6 . 7}$ & 4.8 & 16.1 & 14.0 & & \\
Disagree & $\mathbf{5 4 . 2}$ & 85.9 & 67.2 & 66.0 & & \\
\hline $\begin{array}{l}\text { Easy to find a job } \\
\text { of similar salary }\end{array}$ & & & & & & \\
Agree & $\mathbf{3 4 . 4}$ & 45.0 & 33.5 & 39.1 & 29,958 & $354.67 * *$ \\
Unsure & $\mathbf{5 3 . 7}$ & 10.9 & 19.2 & 15.7 & & \\
Disagree & $\mathbf{1 1 . 9}$ & 44.1 & 47.3 & 45.1 & & \\
\hline
\end{tabular}

*Source: Eurofound, 2017; ** P $<0.001$

\section{Discussion}

The picture emerging from this study is that while most Filipino workers in Malta generally experience positive work outcomes, a significant minority grapples with negative work outcomes and perceptions when compared not only to Maltese nationals and Other EU nationals, but also to other Migrants across the EU28 member states. The ensuing discussion focuses on some of the main challenges faced by the sampled Filipino workers.

This study supports previous research which indicates that while internal migrants in Europe tend to have poorer work outcomes than nationals, the situation is worse among third-country nationals (OECD, 2018). Filipino migrants fare particularly poorly in some of the examined aspects. One of the most alarming results is that nearly half of the Filipino respondents believe that their health or safety is at risk because of their work. One cannot brush aside this finding by attributing it to unrealistically high expectations, since research shows that migrants might be more likely to accept poor working conditions as part of their work (Ahonen et al., 2009). Indeed, two thirds of the respondents in this study are satisfied with their overall working conditions, despite the widespread perceptions of health or safety problems.

Inevitably, the tendency of these workers to be in low skilled jobs such as care-workers and cleaners/housekeepers increases the possibility of health or safety risks, as does the fact that migrants in Malta as in other countries (Gorodzeisky \& Richards, 2013), tend not to be unionised. The mentioned occupations appear to have become 'employment ghettos' for third country nationals in Malta, especially Filipinos, a situation that might further devalue the jobs and lead to worse outcomes.

Greater health and safety risks may result in both employee and employer (or organizational) costs. For example, significantly more Filipino workers take sick leave than the comparison groups in the current study. Having said, the percentage of Filipino workers in Malta taking many days of 
sick leave is less than that of Maltese nationals, perhaps due to their greater fear that extended periods of sick leave may put their job at risk.

Mental health is an important aspect of health and safety at work. The majority of the Filipino respondents experience good relations at work. However, in line with foreign research on migrants (e.g. Ahonen et al., 2009; Calenda, 2014) a substantial third of the respondents perceive not to be treated fairly and they do not feel that their managers and colleagues help and support them. At the same time, Filipinos in Malta seem to be far more likely to experience workplace discrimination or bullying/ harassment when compared to other migrants in the EU. These findings may be tied to the increasing negative sentiment of the Maltese population towards migrants (European Commission, 2018b). They reflect a culture that appears to condone unequal treatment on the basis of one's racial or ethnic background. While one may argue that in general, Malta has adequate laws meant to prevent such abuse, the gap between laws and practice in the EU is well documented (e.g. Islam et al., 2016; Spehar et al., 2017). Insufficient enforcement of employment laws is one contributor to this unhealthy status quo.

Another perhaps more important consideration is the power imbalance between migrant workers and employers deriving from laws that tie migrants' residence status to work permits endorsed by employers. These favour employers while giving scant flexibility to employees (McKay, Jefferys, Paraksevopoulou, \& Keles, 2012). The situation for migrants employed as live-in carers is even more precarious due to intersectionality of female migrants living and working in less transparent, informal, family managed situations which foster the potential for "financial, occupational and sexual exploitation" (Singh 2012, p. 21). A study carried out in Spain indicates that when migrant workers "felt that the risks outweighed the benefits of individually advocating for better conditions, and they lacked the formal structure for such advocacy, possibilities for exploitation are high" (Ahonen et al., 2009, p. 940). It is assumed that Filipinos are less likely to protest against perceived unfair treatment due to the power imbalance that they experience.

In line with research carried out across the EU indicating that $42 \%$ of third-country workers are overqualified for their job (OECD, 2018), the current study found that the sampled Filipino respondents working in Malta tend to be significantly underemployed. While the large majority of respondents have completed post-secondary or tertiary education, most of them ended up in unskilled jobs. The fact that $40 \%$ of the respondents believe to have the skills to cope with more demanding duties is a direct consequence of this state of affairs. Such situation is also consistent with what appears to be the general situation among Filipino overseas workers, who tend to land low-status, manual and service jobs (Semyonov \& Gorodzeisky, 2004). Such underemployment in Malta is influenced by the fact that several post- 
secondary or tertiary qualifications from the Philippines appear not to be fully recognized in this country. Underemployment among migrants has been linked to poor psycho-social well-being and ill health (Dunlavy et al., 2016; Espinoza-Castro et al., 2018).

Foreign research indicates that underemployment may lead to skills loss (Vahabi \& Wong, 2017) and the ensuing decrease of employability and positive career prospects. The fact that Filipino workers are given relatively less training by their employers when compared to Maltese citizens (which might be affected by their over qualification for their jobs, and their potentially short stay in Malta, as indicated by Borg, 2019) does not help their career prospects. It is interesting to note that Filipinos are much more likely than Maltese nationals to pay for their own training. While the current research does not examine the type and quality of training that is carried out, it may be influenced by the respondents' need to boost their employability. Despite this, Filipinos are not likely to develop their careers in this country, as statistics indicate that "very few foreign workers ever change their job or improve their employment occupation while in Malta" (Borg, 2019, p. 4).

Filipino workers in Malta work longer hours than Maltese Nationals, Other EU Nationals or Migrants in the EU28 member states. These findings appear to support previous research indicating that employers expect work flexibility from migrant workers (Ayalon, 2009), a situation that may result in the exploitation of the vulnerable migrants (Ollus, 2016). However, one should note that longer working hours might not necessarily be imposed on these workers. Some of the Filipino workers might 'choose' to work longer hours in order to: send more money to their relatives back home, or return earlier to their country. Indeed, the length of migrants' stay in Malta appears to be rather short (Borg, 2019).

In support of the 'choice' hypothesis mentioned above, this study found a surprisingly high percentage of workers who claim to be able to influence important work decisions, presumably including their long working hours. Nonetheless, an expected consequence of such working regime is that these workers also find it more difficult to fit their work schedule with family or social commitments. It is unclear whether longer hours reduce or accentuate the feelings of loneliness derived from the separation from one's family in the Philippines that has been documented in previous research (e.g. Chowdhury \& Gutman, 2012).

Results also shed light on the Filipino respondents' insufficient knowledge about their work status and the labour market situation in Malta. Indeed, about a third of the respondents were unsure whether they were paid appropriately considering the efforts and achievements in their job. Besides, while a third of the respondents were unsure whether they might lose their job in the next 6 months, more than half were unsure whether it would be easy for 
them to find a job of similar salary if they lose or quit their current job. This apparent disconnection with their surrounding socio-economic situation may be related to the young age of the respondents, their short stay in Malta, and their lack of social integration.

This is the first quantitative study to examine the working conditions of Filipinos in Malta. The respondents experience more challenging working conditions than migrants in general in Europe. This indicates the importance of focusing on particular nationalities of migrants separately in order to better understand their work outcomes. Besides, this study highlights the need to take into consideration the realities of both the home and host countries when analyzing the working situation of migrants, as the emerging dynamics might differ from general findings about migrants.

\section{Conclusion}

This study highlights the employment vulnerability of migrant Filipino workers in Malta by analysing the prevalence of a number of working conditions through the perceptions of the migrants themselves. Whereas most of the surveyed workers are satisfied with their work, many endure bad health or safety conditions. Overall, Filipino workers fair worse than Maltese nationals, Other EU nationals living in their respective countries and also other Migrants across the EU28 member states.

The results point to an apparent structural deficiency in the Maltese society to protect these third country nationals. The social friction created by the fast growth of the migrant population in Malta during the last decade exacerbated the suspicions and fears of the Maltese, resulting in the prevailing negative political discourse and culture that condones unequal treatment of foreigners, the insufficient adoption of inclusive policies and enforcement of effective laws, and the preservation of unfair laws and procedures that reduce the relative power of migrant workers. This study also indicates other specific factors that might be contributing to the prevailing working conditions of Filipinos in Malta, such as their unrecognized qualifications leading to underemployment in low skilled jobs, and the phenomenon of intersectionality. On the other hand, migrants themselves might be choosing some of their difficult working conditions, such as the longer working hours.

The findings of this study have important implications for the Maltese government to better manage the employment integration of Filipino migrants. It is unethical and socially dangerous to continue attracting migrant workers without proper planning and investments into their employment and social integration. The current state of affairs may lead to the strengthening of a dual labour market in which foreign workers often end up working in poor conditions and low levels of security. Such segmentation of the labour market is problematic not only for the affected individuals, but also for the country as 
a whole; it perpetuates social inequality and exclusion, and impedes companies from adapting quickly to the business cycle (Rubery \& Piasna, 2016).

The authors acknowledge that an effective integration of migrants is a complex and challenging phenomenon that requires good will and cooperation at different levels across Malta and the EU. It has been noted that while integrating migrants "is a policy challenge reflecting a multilevel setting, there is little evidence that multilevel governance has emerged" (Spehar et al., 2017, p. 114). Thus, as social and political opposition to the proper assimilation of third country migrants is riding the wave of nationalism across the European countries, creative solutions need to be devised to improve the working lives of vulnerable migrants. Trade unions, employers, government, the Filipino workers themselves and their community groups can all play a role in improving the situation. While specific solutions for the challenges highlighted above go beyond the scope of this paper, it is apparent that substantial improvements would require: awareness raising among the stakeholders about the implications of the current situation; training offered to migrants about employment rights and obligations; stronger enforcement of useful legislation and the changing of unhelpful legislation; and strategies promoting the integration of foreigners in society.

Due to its cross-sectional nature, this study does not provide thorough explanations of the challenges experienced by the respondents. Further in depth research should be carried out to examine the intricate experiences of Filipino workers in specific occupations in Malta, such as care-workers and cleaners/housekeepers. Such experiences might be affected by the interaction of the care, migration and employment regimes in Malta (in line with Williams, 2012). Besides, larger cross sectional studies capturing different nationalities of migrant workers would enable a comparison of their working conditions, which as indicated by foreign research (e.g. Gazioglu \& Sloane, 1994), might differ significantly from each other.

\section{Acknowledgements}

The authors would like to thank: the Consulate of the Republic of the Philippines and the Filipino Community in Malta for providing access to the participants; the European Foundation for the Improvement of Living and Working Conditions for granting permission to use the raw data of the 6th EWCS; Jobsplus (Malta) for supplying data about Filipino workers in Malta.

\section{References:}

1. Ahonen, E. Q., Porthé, V., Vázquez, M. L., García, A. M., LópezJacob, M. J., Ruiz-Frutos, C. et al. (2009). A qualitative study about 
immigrant workers' perceptions of their working conditions in Spain. Journal of Epidemiology \& Community Health, 63, 936-942.

2. Ambrosini, M., \& Barone, C. (2007). Employment and working conditions of migrant workers. Dublin: European Foundation for the Improvement of Living and Working Conditions.

3. Ayalon, L. (2009). Evaluating the working conditions and exposure to abuse of Filipino home care workers in Israel: Characteristics and clinical correlates. International Psychogeriatrics, 21(1), 40-49.

4. Basa, C., Harcourt, W., \& Zarro, A. (2011). Remittances and transnational families in Italy and the Philippines: Breaking the global care chain. Gender \& Development, 19(1), 11-22.

5. Baum, T., Dutton, E., Karimi, S., Kokkranikal, J., Devine, F., \& Hearns, N. (2007). Cultural diversity in hospitality work. Cross cultural management: an international journal, 14(3), 229-239.

6. Borg, I. (2019). The length of stay of foreign workers in Malta. Malta: Central Bank of Malta. Retrieved from https://www.centralbankmalta.org/file.aspx $f=72312$

7. Buttigieg, S. C., Agius, K., Pace, A., \& Cassar, M. (2018). The integration of immigrant nurses at the workplace in Malta: A case study. International Journal of Migration, Health and Social Care, 14(3), 269-289.

8. Calenda, D. (2014). Investigating the working conditions of Filipino and Indian-born nurses in the UK. ILO Asia Pacific Working Paper Series. Philippines: ILO Country Office.

9. Central Bank of Malta. (2016). Assessing the economic impact of foreign workers in Malta. Quarterly Review 2016,1, 39-44. Retrieved from https://www.centralbankmalta.org/quarterly-review

10. Chen, B. (2017). Broken laws and unprotected workers: the conditions of foreign workers in Taiwan. In G. Garofalo Geymonat, S. Marchetti, \& P. Kyritsis (Eds.) "Domestic workers speak: A global fight for rights and recognition", pp.126-129. Retrieved from https://www.academia.edu/36705176/Domestic_workers_speak_a_gl obal_fight_for_rights_and_recognition

11. Chowdhury, R., \& Gutman, G. (2012). Migrant live-in caregivers providing care to Canadian older adults: an exploratory study of workers' life and job satisfaction. Journal of Population Ageing, 5(4), 215-240.

12. CNN Philippines. (2018). EU ambassador to PH: We are here for dev't, non-political agenda. Retrieved from https://cnnphilippines.com/news/2018/01/05/eu-european-unionmarawi-philippines-development.html 
13. Debono, M. (2018). An analysis of trade union membership in Malta. Xjenza, 6, 46-58.

14. del Castillo, I. Y., \& Marzadro, M. (2014). Entre crisis, agencia y retorno: vulnerabilidad de las migrantes bolivianas en Italia/Between crisis, agency and return: the vulnerability of Bolivian migrants in Italy. Revista Cidob d'Afers Internacionals, 129-149.

15. Dunlavy, A. C., Garcy, A. M., \& Rostila, M. (2016). Educational mismatch and health status among foreign-born workers in Sweden. Social Science \& Medicine, 154, 36-44.

16. England, K., \& Henry, C. (2013). Care work, migration and citizenship: international nurses in the UK. Social \& Cultural Geography, 14(5), 558-574.

17. Espinoza-Castro, B., Rueda, L. E. V., Lopez, R. V. M., \& Radon, K. (2018). Working below skill level as risk factor for distress among Latin American migrants living in Germany: a cross-sectional study. Journal of Immigrant and Minority Health, September 8, 1-7.

18. Eurofound. (2017). European working conditions survey integrated data file, 1991-2015, [data collection]. UK Data Service. SN: 7363. Retrieved from https://doi.org/10.5255/UKDA-SN-7363-4

19. Eurofound. (2019). EWCS 2015 questionnaire. Retrieved from https://www.eurofound.europa.eu/surveys/european-workingconditions-surveys/sixth-european-working-conditions-survey2015/ewcs-2015-questionnaire

20. European Commission. (2018a). Commission staff working document - Country Report Malta 2018. Retrieved from https://eurlex.europa.eu/legal-content/FR/ALL/?uri=CELEX:52018SC0216

21. European Commission. (2018b). Results of special Eurobarometer on integration of immigrants in the European Union. Retrieved from https://ec.europa.eu/home-affairs/news/results-specialeurobarometer-integration-immigrants-european-union_en

22. European Commission. (2018c). Spring 2018 economic forecast for Malta. Retrieved from https://ec.europa.eu/info/sites/info/files/economyfinance/ecfin_forecast_spring_030518_mt_en.pdf

23. Eurostat. (2019). Database. Retrieved from https://ec.europa.eu/eurostat/data/database

24. Gazioglu, S., \& Sloane, P. J. (1994). Job disamenities, compensating differences and the immigrant worker: An inter-generational analysis. International Journal of Manpower, 15(7), 44-52.

25. Gorodzeisky, A., \& Richards, A. (2013). Trade unions and migrant workers in Western Europe. European Journal of Industrial Relations, 19(3), 239-254. 
26. Government of Malta. (2002). Chapter 452. Employment and industrial relations act. Retrieved from http://www.justiceservices.gov.mt/DownloadDocument.aspx?app=lo m\&itemid $=8918$

27. Green, O., \& Ayalon, L. (2017). The contribution of working conditions and care recipient characteristics to work-related abuse and exploitation of migrant home care workers. Employee Relations, 39(7), 1001-1014.

28. Iecovich, E. (2011). What makes migrant live-in home care workers in elder care be satisfied with their job?. The Gerontologist, 51(5), 617629.

29. Islam, M. R., Cojocaru, S., Rahman, Z. A., Hajar, A. B. S., \& Arnakim, L. Y. B. (2016). Story behind the closed doors: decent work practice among the migrant domestic workers in Singapore and Italy. Revista de Cercetare si Interventie sociala, 53, 304-325.

30. Jobsplus. (2018a). Filipinos working in Malta 2010-2018. Malta: Jobsplus, Unpublished data.

31. Jobsplus. (2018b). Foreign nationals employment trends. Retrieved from https://jobsplus.gov.mt/resources/publication-statistics-mt-mten-gb/labour-market-information/foreigners-data

32. Kirmayer, L. J., Weinfeld, M., Burgos, G., du Fort, G. G., Lasry, J. C., \& Young, A. (2007). Use of health care services for psychological distress by immigrants in an urban multicultural milieu. The Canadian Journal of Psychiatry, 52(5), 295-304.

33. Koukoulaki, T. (2010). New trends in work environment-New effects on safety. Safety science, 48(8), 936-942.

34. Malta Independent. (2011, January 6). Malta to hire caregivers, seafarers and service providers, Philippine government reports. Retrieved from http://www.independent.com.mt/articles/2011-0106/news/malta-to-hire-caregivers-seafarers-and-service-providersphilippine-government-reports-285803/

35. McKay, S., Jefferys, S., Paraksevopoulou, A. , \& Keles, J. (2012). Study on precarious work and social rights. London: Working Lives Research Institute, London Metropolitan University.

36. Occupational Health and Safety Authority, OHSA, Malta. (2019). Annual report 2018. Retrieved from http://www.ohsa.org.mt

37. OECD. (2018). Settling in 2018: Indicators of immigrant integration. Retrieved from http://www.oecd.org/publications/indicators-ofimmigrant-integration-2018-9789264307216-en.htm

38. Ollus, N. (2016). Forced flexibility and exploitation: experiences of migrant workers in the cleaning industry. Nordic journal of working life studies, 6(1), 25-45. 
39. Pillinger, J. (2016). Psychosocial risks and violence in the world of work: A trade union perspective. International Journal of Labour Research, 8(1/2), 35 .

40. Ronda, E., Agudelo-Suárez, A. A., García, A. M., López-Jacob, M. J., Ruiz-Frutos, C., \& Benavides, F. G. (2013). Differences in exposure to occupational health risks in Spanish and foreign-born workers in Spain (ITSAL Project). Journal of immigrant and minority health, 15(1), 164-171.

41. Rosano, A., Dauvrin, M., Buttigieg, S. C., Ronda, E., Tafforeau, J., \& Dias, S. (2017). Migrant's access to preventive health services in five EU countries. BMC Health Services Research, 17(1), 588.

42. Rubery, J., \& Piasna, A. (2016). Labour market segmentation and the EU reform agenda: Developing alternatives to the mainstream. ETUI Research Paper-Working Paper 2016/10.

43. Sales, R. (2007). Giving more than they receive? Migrant women and welfare in Britain. International Journal of Migration, Health and Social Care, 3(3), 6-19.

44. Schilgen, B., Nienhaus, A., Handtke, O., Schulz, H., \& Mösko, M. (2017). Health situation of migrant and minority nurses: A systematic review. PloS one, 12(6), 1-28.

45. Semyonov, M., \& Gorodzeisky, A. (2004). Occupational destinations and economic mobility of Filipino overseas workers. International Migration Review, 38(1), 5-25.

46. Singh, S. (2012). Domestic problems. Herizons, Fall 2012, 18-23. Retrieved from https://www.thefreelibrary.com

47. Spehar, A., Hinnfors, J., \& Bucken-Knapp, G. (2017). Passing the Buck: The case of failing multilevel governance and vulnerable EU migrants in Sweden. Nordic Journal of Migration Research, 7(2), 114123.

48. Sterud, T., Tynes, T., Mehlum, I. S., Veiersted, K. B., Bergbom, B., Airila, A., et al. (2018). A systematic review of working conditions and occupational health among immigrants in Europe and Canada. BMC Public Health, 18(1), 770.

49. Supangco, V., \& Mayrhofer, W. (2014). Determinants of work role transition outcomes of Filipinos in Singapore. Journal of Global Mobility, 2(3), 317-342. 
50. Times of Malta. (January 20, 2019). Malta will need another 13,000 foreign workers this year. Retrieved from https://www.timesofmalta.com/articles/view/20190120/local/maltawill-need-another-13000-foreign-workers-this-year.699691

51. Vahabi, M., \& Wong, J. P. H. (2017). Caught between a rock and a hard place: mental health of migrant live-in caregivers in Canada. BMC Public Health, 17(1), 498.

52. Williams, F. (2012). Converging variations in migrant care work in Europe. Journal of European Social Policy, 22(4), 363-376. 